\title{
Microsatellites for the highly invasive Cameraria ohridella (Lepidoptera: Gracillariidae) and their amplification in related species
}

\author{
Neus MARi MENA, Romain VALADE, Emmanuelle MAGNOUX, Sylvie AUGUSTIN \\ and CARLOS LOPEZ-VAAMONDE*
}

\begin{abstract}
INRA, URZF 633, Centre d'Orléans, Unité de Zoologie Forestière, 2163 Avenue de la Pomme de Pin; CS 40001 Ardon, 45075
Orléans, Cedex 2, France; e-mail: carlos.lopez-vaamonde@orleans.inra.fr
\end{abstract}

Key words. Gracillariidae, Aesculus hippocastanum, Cameraria ohridella, horse chestnut leafminer, invasion, microsatellites, Phyllonorycter platani

\begin{abstract}
A set of six polymorphic microsatellite markers was developed for the highly invasive horse chestnut leaf-mining moth, Cameraria ohridella. For 96 positive clones, six polymorphic microsatellites with conserved flanking regions were identified. The average number of alleles per locus was eight (range from three to 12). Two of these loci showed significant heterozygosity deficits due to null alleles. The remaining four loci did not depart from Hardy-Weinberg equilibrium. In addition, all six loci were amplified for 20 other gracillariid species belonging to eight different genera, including another invasive species Phyllonorycter platani. These are the first microsatellite markers described for a species within the lepidopteran family Gracillariidae.
\end{abstract}

\section{INTRODUCTION}

Here we report on the isolation and characterization of six polymorphic microsatellite loci in the horse-chestnut leafmining moth, Cameraria ohridella Deschka \& Dimíc, 1986 (Lepidoptera: Gracillariidae). This micro moth was first found in Macedonia in the early 1980's. Since then, it has spread over Europe and its distribution now covers most of Europe. Its main host, the common horse-chestnut (Aesculus hippocastanum) is an important urban tree, which is now often severely defoliated.

\section{MATERIAL AND METHODS}

DNA extractions were obtained using the DNeasy Tissue Kit (Qiagen, Courtaboeuf, France) following the manufacturer's instructions. An enriched library was constructed from 54 adult moths by Ecogenics GmbH (Zurich, Switzerland) from size selected genomic DNA ligated into SAULA/SAULB-linker (Armour et al., 1994) and enriched by magnetic bead selection with biotin-labeled (GT)13, (CT)13, (GATA)7, and (CATA)7 oligonucleotide repeats (Gautschi et al., 2000a, b). Of the 853 recombinant colonies screened, 96 gave a positive signal after hybridization. Plasmids from 58 positive clones were sequenced and primers were designed for 35 microsatellite inserts using Oligo 3.3 (Molecular Biology Insights, Inc. Cascade, Colorado, USA). Out of 35 primer pairs 9 gave clear bands, which were seen to be polymorphic when run on a $3 \%$ agarose gel. The other 26 primer pairs gave multiple, weak or monomorphic bands and were therefore excluded from further analyses.

TABLE 1. Characteristics of six polymorphic microsatellite loci in Cameraria ohridella. Polymorphism statistics were calculated based on data from 31 individuals collected in a natural stand of Aesculus hippocastanum in Perivoli, Greece (39 $\left.58^{\prime} 0.73^{\prime \prime} \mathrm{N}, 21^{\circ} 12^{\prime} 0.60^{\prime \prime} \mathrm{E}\right)$.

\begin{tabular}{|c|c|c|c|c|c|c|c|c|c|c|c|}
\hline $\begin{array}{l}\text { Locus name } \\
\text { (GeneBank } \\
\text { Accession } \\
\text { No.) }\end{array}$ & $\begin{array}{c}\text { Repeat } \\
\text { motif }\end{array}$ & Primer sequences $\left(5^{\prime} \rightarrow 3^{\prime}\right)$ & $\begin{array}{l}\mathrm{T}_{\mathrm{a}} \\
\left({ }^{\circ} \mathrm{C}\right)\end{array}$ & $\begin{array}{c}\mathrm{MgCl}_{2} \\
(\mathrm{mM})\end{array}$ & $\begin{array}{l}\text { No. of } \\
\text { alleles }\end{array}$ & $\begin{array}{l}\text { Allele } \\
\text { size } \\
\text { range } \\
\text { (bp) }\end{array}$ & $\mathrm{H}_{\mathrm{O}}$ & $\mathrm{H}_{\mathrm{E}}$ & $\mathrm{N}_{\mathrm{i}}$ & NA & HWE \\
\hline Ohrid2753 & $(\mathrm{CA})_{11}$ & $\begin{array}{l}\text { F: FAM-AGAGGCCATAGGCGCTTAAC } \\
\text { R: AGTAGAGGACGCCCACGAAG }\end{array}$ & 53.6 & 2.5 & 11 & $215-237$ & 0.8710 & 0.8821 & 31 & -0.0057 & 0.0786 \\
\hline Ohrid2759 & $(\mathrm{AG})_{22}$ & $\begin{array}{l}\text { F: NED-AAGGAGTTGGCACAGGACAG } \\
\text { R: GGGTATCGGACAAGTTTTAACG }\end{array}$ & 52.1 & 2 & 12 & 149-199 & 0.7419 & 0.7446 & 31 & -0.0023 & 0.1398 \\
\hline Ohrid2762 & $(\text { CATA })_{6}$ & $\begin{array}{l}\text { F: NED-TTGCTCGTCTTCCAAGTCCC } \\
{ }^{6} \text { R: TCCGACCAACCCCAACAC }\end{array}$ & 54.6 & 2 & 5 & $117-137$ & 0.1613 & 0.5547 & 31 & +0.5333 & $P<0.001$ \\
\hline Ohrid2782 & $(\mathrm{GT})_{9}$ & $\begin{array}{l}\text { F: HEX-TTCTTTATTGGCTTATCCGC } \\
\text { R: CTGCATAATCTAAGTTTCCATGTC }\end{array}$ & 50.3 & 2 & 9 & $109-131$ & 0.8065 & 0.8065 & 31 & -0.0075 & 0.9823 \\
\hline Ohrid2794 & $(\mathrm{CA})_{12}$ & $\begin{array}{l}\text { F: PET- CTGCATAATCTAAGTTTCCATGTC } \\
\text { R: TTCTTTATTGGCTTATCCGG }\end{array}$ & 50.4 & 2 & 8 & $113-133$ & 0.8387 & 0.8350 & 31 & -0.0127 & 0.8874 \\
\hline Ohrid2814 & $(\mathrm{CA})_{9}$ & $\begin{array}{l}\text { F: FAM-ACCGTAAAGATAATATTTAACCCG } \\
\text { R: GTGAAAGTTTTTGTTTGAATTAGC }\end{array}$ & 50.6 & 1.5 & 3 & $103-107$ & 0.1071 & 0.4253 & 28 & +0.6061 & $P<0.001$ \\
\hline
\end{tabular}

$\mathrm{T}_{\mathrm{a}}$ - optimal annealing temperature; $\mathrm{H}_{\mathrm{O}}$ - observed heterozygosity; $\mathrm{H}_{\mathrm{E}}$ - expected heterozygosity; $\mathrm{N}_{\mathrm{i}}$ - number of individuals successfully amplified out of the 31 individuals tested; NA - null allele frequency estimate; HWE - probability of the population being in HardyWeinberg equilibrium.

* Corresponding author. 
TABLE 2. Number of alleles observed in cross-amplifications of six Cameraria ohridella microsatellite loci of 66 individuals belonging to 20 gracillariid species. $\mathrm{N}$ - number of individuals assayed per species. (-) indicates no amplification or inconsistent amplification. Allele size range (bp) are indicated between parentheses.

\begin{tabular}{|c|c|c|c|c|c|c|c|}
\hline Species name, host plant, country (voucher number) & $\mathrm{N}$ & Ohrid2753 & Ohrid2759 & Ohrid2762 & Ohrid2782 & Ohrid2794 & Ohrid2814 \\
\hline Cameraria sp1 ex Ulmus, Japan (RV22) & 1 & $2(125-131)$ & $2(157-173)$ & - & - & - & $1(105)$ \\
\hline Cameraria sp2 ex Acer, Japan (RV27) & 1 & $1(223)$ & $2(157-173)$ & $1(135)$ & $2(123-127)$ & - & $1(105)$ \\
\hline $\begin{array}{l}\text { Cameraria gaultheriella ex Gaultheria shallon USA } \\
\text { (RV28) }\end{array}$ & 1 & - & $1(157)$ & - & $1(125)$ & - & $\begin{array}{c}2 \\
(103-105)\end{array}$ \\
\hline Cameraria sp3 ex Ostrya virginiana USA (RV39) & 1 & - & $2(157-173)$ & - & $2(125-127)$ & - & $1(105)$ \\
\hline $\begin{array}{l}\text { Cameraria sp4 ex Lithocarpus densiflorus, USA } \\
\text { (RV102) }\end{array}$ & 1 & - & $2(157-173)$ & - & $1(125)$ & $2(127-129)$ & $2(103)$ \\
\hline $\begin{array}{l}\text { Cameraria sp5 ex Quercus crassipes, Mexico } \\
\text { (RV113) }\end{array}$ & 1 & - & $2(157-173)$ & - & - & $2(127-129)$ & $\begin{array}{c}2 \\
(103-105)\end{array}$ \\
\hline Cameraria sp6 ex Annonaceae, Vietnam (RV124) & 1 & - & - & - & $1(125)$ & $2(127-129)$ & $1(105)$ \\
\hline $\begin{array}{l}\text { Cameraria sp7 ex Aesculus turbinata, Japan } \\
\text { (RV176) }\end{array}$ & 1 & - & $1(157)$ & - & $2(125-127)$ & $2(127-129)$ & $\begin{array}{c}2 \\
(103-105)\end{array}$ \\
\hline Cameraria sp8 ex Acer japonicum, Japan (RV178) & 1 & - & $1(179)$ & $1(201)$ & $1(123)$ & $2(127-129)$ & $\begin{array}{c}2 \\
(103-105)\end{array}$ \\
\hline Cameraria sp9 ex Acer mono, Japan (RV180) & 1 & - & $1(157)$ & - & $2(125-127)$ & - & $\begin{array}{c}2 \\
(103-105)\end{array}$ \\
\hline $\begin{array}{l}\text { Cameraria sp10 ex Acer pseudosieboldianum, } \\
\text { Japan (RV181) }\end{array}$ & 1 & - & $2(157-173)$ & - & - & $2(127-129)$ & $1(105)$ \\
\hline Phyllonorycter platani, ex Platanus France & 1 & $2(205-221)$ & $2(157-173)$ & $1(191)$ & $2(125-127)$ & $2(127-129)$ & $\begin{array}{c}2 \\
(103-105)\end{array}$ \\
\hline $\begin{array}{l}\text { Epicephala sp. ex Glochidion obovatum Japan } \\
\text { (EM1-EM12) }\end{array}$ & 12 & $5(223-239)$ & $4(149-185)$ & - & $3(121-125)$ & - & - \\
\hline $\begin{array}{l}\text { Diphtheroptila scripulata ex Glochidion obovatum } \\
\text { Japan (EM13-EM23) }\end{array}$ & 11 & - & $1(157)$ & - & $5(119-125)$ & $2(127-129)$ & - \\
\hline $\begin{array}{l}\text { Acrocercops transecta ex Juglans ailanthifolia, } \\
\text { Japan (EM24-EM29) }\end{array}$ & 12 & - & - & - & - & - & - \\
\hline $\begin{array}{l}\text { Acrocercops transecta ex Lyonia ovalifolia, Japan } \\
\text { (EM32-EM37) }\end{array}$ & 6 & - & $1(157)$ & - & - & $1(127)$ & - \\
\hline $\begin{array}{l}\text { Acrocercops defigurata ex Juglans regia, Nepal } \\
\text { (EM43) }\end{array}$ & 1 & - & $1(157)$ & - & $2(123-127)$ & $1(127)$ & - \\
\hline $\begin{array}{l}\text { Acrocercops defigurata ex Engelhardtia spicata, } \\
\text { Nepal (EM44) }\end{array}$ & 1 & - & $1(157)$ & - & - & - & - \\
\hline $\begin{array}{l}\text { Acrocercops leucophaea ex Engelhardtia spicata } \\
\text { Nepal (EM38-EM39) }\end{array}$ & 2 & - & - & - & - & - & $1(103)$ \\
\hline $\begin{array}{l}\text { Acrocercops leucophaea ex Lyonia ovalifolia Nepal } \\
\text { (EM45-EM46) }\end{array}$ & 2 & - & - & - & - & - & - \\
\hline $\begin{array}{l}\text { Gibbovalva magnoliae ex Magnolia obovata, Japan } \\
\text { (EM30-EM31) }\end{array}$ & 2 & $1(223)$ & - & - & $1(127)$ & - & - \\
\hline $\begin{array}{l}\text { Deoptilia heptadeta ex Mallotus japonicus, Japan } \\
\text { (EM40-EM42) }\end{array}$ & 3 & - & - & - & $1(123)$ & $1(127)$ & - \\
\hline $\begin{array}{l}\text { Psydrocercops wisteriae ex Wisteria floribunda } \\
\text { Japan (EM47-EM48) }\end{array}$ & 2 & - & - & - & $3(93-127)$ & $2(127-129)$ & $1(103)$ \\
\hline
\end{tabular}

In addition, for each of these nine polymorphic loci, the alleles of two heterozygous individuals were cloned and seven clones were sequenced per individual and per locus $(\mathrm{N}=126$ clones sequenced) to determine the true allele lengths and presence of mutations within the flanking regions. Alleles were ligated into PCR2.1 (Invitrogen, Paisley, UK). Using the plasmid primers, M13 forward and M13 reverse; the inserts of seven positive clones for each ligation were amplified and sequenced. Sequencing was performed using the Big-Dye Terminator Sequencing 3.1 Kit (Applied Biosystems, Courtaboeuf, France) on an ABI 3100 genetic analyser (Applied Biosystems).
Out of the nine polymorphic microsatellites analysed, three showed variability within the flanking regions and were therefore excluded from further analyses. Characteristics of the six remaining microsatellites with conserved flanking regions are summarized in Table 1. Five of these microsatellites showed a dinucleotide motif, whereas variability in locus Ohrid2762 was due to a tetranucleotide repeat (Table 1).

The six selected primer pairs were tested for polymorphism in 31 larvae of Cameraria ohridella collected from a natural stand of Aesculus hippocastanum (Table 1). PCR amplifications were carried out using a MJ Research PTC100 thermal cycler and the 
RedTaq package (Sigma-Aldrich Chimie S.a.r.l., Lyon, France). The total volume reaction was $10 \mu \mathrm{L}$, containing $10 \mathrm{ng}$ of genomic DNA, 0.4 units of Taq DNA polymerase (Sigma), $1 \times$ buffer ( $100 \mathrm{mM}$ Tris $\mathrm{HCl}, 500 \mathrm{mM} \mathrm{KCl}$ and $0.1 \%$ gelatine), 20 $\mathrm{mg} / \mathrm{L}$ of BSA, $250 \mu \mathrm{M}$ of each dNTP, $0.4 \mu \mathrm{M}$ of each primer. $\mathrm{MgCl}_{2}$ concentration is given in Table 1. Forward and reverse primer was synthesized and 5'-labelled with a fluorescent dye, either 6-FAM, PET, HEX (Sigma) or NED (Applied Biosystems). PCR conditions were $3 \mathrm{~min}$ at $95^{\circ} \mathrm{C}$ followed by 35 cycles of $50 \mathrm{~s}$ at $95^{\circ} \mathrm{C}, 1 \mathrm{~min}$ at optimal annealing temperature (Table 1), $45 \mathrm{~s}$ at $72^{\circ} \mathrm{C}$, and $15 \mathrm{~min}$ at $72^{\circ} \mathrm{C}$. The amplified products were detected on an ABI-3100 automatic sequencer and their sizes estimated using Genescan software (Applied Biosystems).

Observed and expected heterozygosities and tests for departure from Hardy-Weinberg equilibrium (HWE) were calculated using Cervus 3.0.3 software (Marshall et al., 1998). Tests for linkage disequilibrium were conducted using a Markov Chain method (1000 dememorisation steps, 100 batches, and 1000 iterations per batch) in Genepop web version 3.4 software (Raymond \& Rousset, 1995). In addition, Microchecker (Van Oosterhout et al., 2004) was used to test for null alleles and identify possible scoring errors due to large-allele dropout and stuttering.

We also tested the selected six primers for amplification using 20 other gracillariid species belonging to eight different genera, including another invasive species, Phyllonorycter platani (Table 2). The amplified products were detected on an ABI3100 automatic sequencer and their sizes estimated using GENESCAN software (Applied Biosystems).

\section{RESULTS AND DISCUSSION}

The average number of alleles per locus was eight (range from three to 12). Observed heterozygosity values ranged from 0.1071 to 0.8710 ; expected heterozygosity from 0.4253 to 0.8821 . No linkage disequilibrium was observed for any pair of loci. Micro-Checker found no evidence of large-allele dropout. However, significant deviation from HWE and evidence for null alleles were observed at least in two (Ohrid2814 and Ohrid2762) of the 6 loci analysed (Table 1). In each case, significant deviations were the result of an excess of homozygotes. These departures from HWE can be due to the presence of null alleles, strong inbreeding or selection for or against a certain allele (Selkoe \& Toonen, 2006)

Across all 66 gracillariid individuals genotyped, amplification success varied from $6.1 \%$ (locus Ohrid2753) to $25.8 \%$ (locus Ohrid2759). However, amplification success was much higher among Cameraria, ranging from $18.2 \%$ (locus Ohrid2753) to 100\% (locus Ohrid2814).

It is worth noting the high success rate of amplification within the Cameraria genus and in particular in Phyllonorycter platani for which all six loci amplified. This is not suprising since Phyllonorycter is considered to be a sister taxa of Cameraria (Lopez Vaamonde et al., 2003). Therefore the microsatellites characterized for $C$. ohridella could also be used to study the invasion genetics of $P$. platani. This species is also interesting since it shows a similar geographical expansion pattern as Cameraria ohridella. Indeed, both invasive species have a Balkanic origin and have progressively colonized all western and central Europe over the last 20 years (Šefrová, 2001). In addition, these newly generated polymorphic microsatellites could also be used to study the molecular ecology of the mutualistic association between Epicephala moths and Glochidion trees (Kawakita \& Kato, 2006).

Developing microsatellite markers for Lepidoptera is a difficult task. Researchers face several problems: presence of non amplifying alleles (null alleles) (Cassel-Lundhagen, 2002; Habel et al., 2008), excess of homozygotes compared to that predicted by the Hardy-Weinberg equilibrium (Anderson et al., 2006), and similar flanking regions (Meglécz et al., 2004, 2007). We encountered most of these problems in C. ohridella, which explains the relatively low number of polymorphic microsatellites isolated in our study. Despite those difficulties, the microsatellite markers developed here will be useful for studying the genetic variability of $C$. ohridella across its geographical distribution and for identifying its area of origin.

ACKNOWLEDGEMENTS. We are most grateful to N. Avtzis, G. Grabenweger, O. Issei, A. Kawakita, M. Kenis and E. Van Nieukerken for providing samples. Thanks to both S. Delamaire and J. Rousselet for their technical advice and M. Vila for comments on an earlier version of this manuscript.

\section{REFERENCES}

Anderson S.J., Dawson D.A. \& Freeland J.R. 2006: Isolation and characterization of highly polymorphic microsatellite loci for the garden tiger moth Arctia caja (Lepidoptera: Arctiidae). Mol. Ecol. Notes 6: 104-106.

Armour J.A., Neumann R., Gobert S. \& Jeffreys A.J. 1994: Isolation of human simple repeat loci by hybridization selection. Hum. Mol. Genet. 3: 599-565.

Cassel-Lundhagen A. 2002: Characterization of microsatellite loci in Coenonympha hero (Lepidoptera: Nymphalidae). Mol. Ecol. Notes 2: 566-568.

Gautschi B., Tenzer I., Müller J.P. \& Schmid B. 2000a: Isolation and characterization of microsatellite loci in the bearded vulture (Gypaetus barbatus) and crossamplification in three Old World vulture species. Mol. Ecol. 9: 2193-2195.

Gautschi B., Widmer A. \& Koella J. 2000b: Isolation and characterization of microsatellite loci in the Dice Snake (Natrix tessellata). Mol. Ecol. 9: 2191-2193.

Habel J.C., Finger A., Meyer M., Schmitt T. \& Assmann T. 2008: Polymorphic microsatellite loci in the endangered butterfly Lycaena helle (Lepidoptera: Lycaenidae). Eur. J. Entomol. 105: 361-362.

KaWAKITA A. \& Kato M. 2006: Assessment of the diversity and species specificity of the mutualistic association between Epicephala moths and Glochidion trees. Mol. Ecol. 15: $3567-3581$.

Lopez-VAamonde C., Godfray H.C.J. \& CoOK J.M. 2003: Evolutionary dynamics of host-plant use in a genus of leaf-mining moths. Evolution 57: 1804-1821.

Marshall T.C., Slate J., Kruuk L. \& Pemberton J.M. 1998: Statistical confidence for likelihood-based paternity inference in natural populations. Mol. Ecol. 7: 639-655.

Meglécz E., Péténian F., Danchin E., Ceeur D’Acier A., RasPLUS J.-Y. \& FAURE E. 2004: High similarity between flanking regions of different microsatellites detected within each of two species of Lepidoptera: Parnassius apollo and Euphydryas aurinia. Mol. Ecol. 13: 1693-1700.

Meglécz E., Anderson A., Bourget D., Butcher R., Caldas A., Cassel-Lundhagen A., Ceeur D'Acier A., Dawson A.D., Faure N., Fauvelot C., Franck P., Harper G., Keyghobadi N., Kluetsch C., Muthulakshmi M., Nagaraju J., Patt A., PÉténian F., Salivain J.F. \& Wilcock H. 2007: Microsatellite flanking region similarities among different loci within insect species. Insect Mol. Biol. 16: 175-185.

Raymond M. \& Rousset F. 1995: Genepop (version 1.2): Population genetics software for exact tests and ecumenicism. $J$. Hered. 86: 248-249. 
Š́frová H. 2001: Phyllonorycter platani (Staudinger) - a review of its dispersal history in Europe (Lepidoptera, Gracillariidae). Acta Univ. Agric. Silvic. Mendel. Brun. 49: 71-75.

Selkoe K.A. \& Toonen R.J. 2006: Microsatellites for ecologists: a practical guide to using and evaluating microsatellite markers. Ecol. Lett. 9: 615-629.
Van Oosterhout C., Hutchinson W.F., Wills D.P.M. \& SHIPLEY P. 2004: Micro-checker: Software for identifying and correcting genotyping errors in microsatellite data. Mol. Ecol. Notes 4: 535-538.

Received August 13, 2008; revised and accepted September 5, 2008 